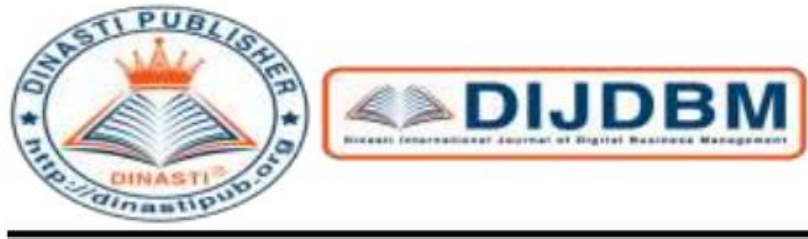

+628138765 4578

+6281387654578

https://dinastipub.org/DIJDBM editor@dinastipub.org

\title{
THE EFFECT OF PROFITABILITY, CAPITAL STRUCTURE AND CORPORATE VALUES ON RETURN OF SHARES (TELECOMMUNICATIONS SUB SECTOR IN INDONESIA STOCK EXCHANGE 2014-2018)
}

\author{
Asih Try Wulandari' ${ }^{1)}$, Aty Herawati ${ }^{2}$ \\ ${ }^{1,2}$ Postgraduate Masters in Management, Mercubuana University, Jakarta, Indonesia
}

\begin{tabular}{|c|c|}
\hline $\begin{array}{l}\text { ARTICLE INFORMATION } \\
\text { Received: } 3 \text { January } 2020 \\
\text { Revised: } 9 \text { January } 2020 \\
\text { Issued: } 13 \text { January } 2020 \\
\text { Corresponding author: } \\
\text { Asih try Wulandari } \\
\text { E-mail: } \\
\text { asihtrywulandari@gmail.com } \\
\text { aty_herawati@ mercubuana.ac.id } \\
\end{array}$ & $\begin{array}{l}\text { Abstract: The development of increasingly stringent } \\
\text { business world in Indonesia will create an increasingly sharp } \\
\text { competition between companies. Firms in the industry in } \\
\text { Indonesia is a land for investors to invest capital to be } \\
\text { invested in various forms of securities. So it is not wrong for } \\
\text { the company's various aspects and types become part of the } \\
\text { capital market. This study was conducted to determine the } \\
\text { effect of ROE, DER and PBV to Stock Return on } \\
\text { Telecommunications Sector Sub Listed in Indonesia Stock } \\
\text { Exchange. This study uses annual data for the observation } \\
\text { period from } 2014 \text { until } 2018 \text {. The research type is descriptive } \\
\text { causality. The data used is the data panel that is a } \\
\text { combination of annual time series data and cross section } \\
\text { were processed using panel data regression analysis. The } \\
\text { population is all Sub-Sector Telecommunications listed in } \\
\text { Indonesia Stock Exchange from } 2014 \text { until } 2018 \text { the number } \\
\text { of } 5 \text { companies. The sampling technique used purposive } \\
\text { sampling, found a sample of four companies with the } \\
\text { observation of } 5 \text { years in order to obtain total observation as } \\
\text { much as } 20 \text {. Data were obtained from the Indonesia Stock } \\
\text { Exchange, and Yahoo Finance. Analysis of the data in this } \\
\text { study is panel data regression. The model used is the } \\
\text { Common Effect Model. The analysis showed that the ROE } \\
\text { does not have a significant effect on stock returns, DER has } \\
\text { no significant effect on stock returns, while PBV positive } \\
\text { and significant effect Stock Return on Telecommunications } \\
\text { Sector Sub Listed in Indonesia Stock Exchange. } \\
\text { Keywords: : ROE, DER, PBV and Stock Return }\end{array}$ \\
\hline
\end{tabular}

\section{INTRODUCTION}

The development of increasingly stringent business world in Indonesia will create an increasingly sharp competition between companies. The companies in the industry in Indonesia is a land for investors to invest capital to be invested in various forms of securities. So it is not wrong for the company's various aspects and types become part of the capital market. 
Capital market in Indonesia has a lot of sectors one of which is infrastructure, utilities and transportation are companies which development is very fast and good. The amount of funds expended in the construction of infrastructure, utility and transportation to be an indicator that a country is very dedicated in providing the best facilities for its residents. Besides having great benefits Infrastructure, Utilities and Transportation has also become a critical success factor in the Indonesian economy. Infrastructure, Utilities and Transport are growing rapidly and could push the country's revenue and support economic growth in Indonesia.

Table 1. Data Return Equity Infrastructure Sector, Utilities and Transportation

\begin{tabular}{lcccc}
\hline \multirow{2}{*}{ SUB SECTOR } & \multicolumn{4}{c}{ STOCK RETURNS } \\
\cline { 2 - 5 } & $\mathbf{2 0 1 5}$ & $\mathbf{2 0 1 6}$ & $\mathbf{2 0 1 7}$ & $\mathbf{2 0 1 8}$ \\
\hline Energy & -0.23690 & 0.05483 & 0.09395 & 0.01153 \\
Non-Building Construction & -0.09299 & 0.61935 & 0.41614 & 0.07543 \\
transportation & -0.21517 & 0.19664 & -0.04537 & 0.20532 \\
Telecommunication & -0.01567 & 0.12263 & -0.02982 & 0.28004 \\
$\begin{array}{l}\text { Toll Roads, Ports, Airports and } \\
\text { the like }\end{array}$ & -0.00412 & -0.14486 & 0.13696 & -0.07964 \\
\hline
\end{tabular}

Sub-Sector Telecommunications trending stock returns that are best compared sub other sectors actually showing an increase very significantly in 2018 when compared to the stock return sub other sectors, this is because the Telecommunications Market in Indonesia is still great and still plenty of room to develop into bigger,

Investment decision making course begins with an analysis of the financial ratios of the company's financial statements. Profitability, Capital Structure and Corporate Values included in the composition of financial ratios are an important consideration for investors.

Based on the above, it should be investigated stock returns Telecommunications sub-sector in Indonesia Stock Exchange (BEI) in the period 2014- 2018 by using the ROE, DER, PBV.

\section{LITERATURE REVIEW}

Ross (1976) revealed that the Arbitrage Pricing Theory (APT) is based on the premise that states that two (2) investment opportunities have the same characteristics are not able to be sold at different prices, further this theory assumes that the level of such benefits can be affected by various factors systematic. The correlation between the rate of profit of 2 (two) securities occurs because the securities are influenced by several factors the same.

Signaling Theory or signal theory developed by (Ross, 1977), stated that the company executives have better information about the company will be compelled to pass on the information to potential investors that its stock price increase.

Profitability ratio According to Winarto (2015), Profitability ratio is the ratio to assess the ability of the enterprise for profit. This ratio also provides a measure of the effectiveness of management of a company. Return On Equity (ROE) to measure profitability, with net income formulas available to common shareholders divided by the number of equity shares. The following formula can be used to calculate the Return On Equity (ROE):

$$
\text { ROE }=\frac{\text { Earning After Tax }}{\text { Total Equity }}
$$


Capital Structure According to Fahmi (2014), the capital structure is the ratio of debt to equity is a ratio used to measure the proportion of debt to equity. Debt to Equity Ratio (DER) is a ratio used to measure a company's debt incurred compares to their own capital. DER measurement units are as follows:

$$
\text { DER }=\frac{\text { Total Liabilities }}{\text { Total Equity }}
$$

Company Value, According Pantow et al (2015), The company's value is a company's performance, as reflected by the stock price is formed by supply and demand in the capital markets that reflect the public's assessment of the performance of the company. Price to Book Value (PBV) is the ratio of the market used to measure performance against the market price of their book value, which is projected by the following formula:

$$
\mathrm{PBV}=\frac{\text { Market Price }}{\text { Book Value }}
$$

Return Stocks, Gitman (2012) is the total gain or loss on an investment over a given period. This is usually measured as the change in value added distribution of cash over a period of time, expressed as a percentage of the value of the initial investment period.

$$
\mathrm{Rs}=\frac{\mathrm{Pt}-\mathrm{Pt}-1}{\mathrm{Pt}-1}
$$

Information:

Rs : Stock returns

Pt : The stock price of the current period

Pt-1 : The share price the previous period

This research has been carried out by some previous investigators related to profitability, capital structure, corporate value and stock returns, such as: Nuryaman (2015), Winarto (2015), Tamuunu and Farlane (2015), Pantow et al (2015), Tofu Susilo (2017), Mahdaleta et al (2016), Tran Nha Ghi (2015), Rashid (2015), Hasbi (2015), Abdullah et.al (2015), Adnan Gharaibeh (2014), Dita and Isrochmani (2014), Senyigit and Ag (2014), Emamgholipou r et. al (2013), Herath (2017), Martini et al (2014)

Based on the literature reviews that Mentioned avobe, the theoretical framework of the research is as follows:

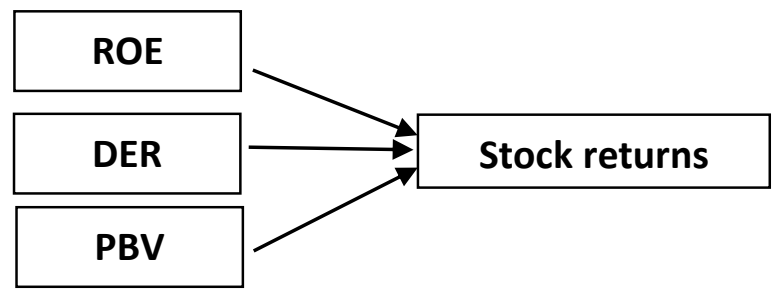

Figure 1. Theoretical Framework 


\section{RESEARCH METHODS}

This type of research is associative research, the research aims to examine the influence or relationship between two or more variables (Sugiyono, 2014). In this study, researchers will analyze the effect of variable profitability, capital structure, and Value to Return Sub-Sector Shares Telecommunications Company Listed in Indonesia Stock Exchange (IDX), which amounts to five companies from 2014 until 2018. The samples were collected from four companies Telecommunications, Panel data regression analysis is used to determine the effect of the independent variable on the dependent variable.

Panel data regression equation is as follows:

Yit $=\alpha+\beta$ Xit $+\varepsilon$ it

Where:

Yit $=$ Variable response at the $\mathrm{i}$-th observation units and time to $\mathrm{t}$

Xit $=$ The predictor variables in the $\mathrm{i}$-th observation units and time to $\mathrm{t}$

$\alpha \quad=$ Intercept regression model

$\beta=$ Slope coefficient or coefficients directions

eit $=$ Component error on the $\mathrm{i}$-th observation units and time to $\mathrm{t}$

Then, a test on the goodness of fit model (F-test) is conducted. This test is used to Determine Whether all of the independent variables Affect the dependent variables or not (the goodness of fit models). If the models is significant, then we will see the result of the coefficient of determination. The coefficient of determinationused to measure how far the model's ability to explain variations in the dependent variable. R2 small value means the ability of independent variables in explaining the variation of the dependent variable are very limited. A value close to the mean of independent variables provide almost all the information needed to predict the variation of the dependent variable (Ghozali, 2006). Furthermore $t$ test, $t$ test showed how far the influence of the independent variable (independent) individually in explaining the variation of the dependent variable. (Ghozali, 2006).

\section{FINDINGS AND DISCUSSION}

Dependent Variable: Y

Method: Panel Least Squares

Date: 11/19/19 Time: 10:59

Sample: 20142018

Periods included: 5

Cross-sections included: 4

Total panel (balanced) observations: 20

\begin{tabular}{crrrr}
\hline \hline variable & coefficient & Std. Error & t-Statistic & Prob. \\
\hline \hline C & -1.461331 & 1.082110 & -1.350446 & 0.1957 \\
X1 & 5.823832 & 3.386512 & 1.719714 & 0.1048 \\
X2 & 0.044281 & 0.061870 & 0.715716 & 0.4845 \\
X3 & 3.332911 & 0.773949 & 4.306372 & 0.0005
\end{tabular}


R-squared

Adjusted R-squared

SE of regression

Sum squared resid

Log likelihood

F-statistic

Prob (F-statistic)
0.618158Mean dependent var

1.008440

0.546562SD dependent var

4.500645

3.030635Akaike information criterion

5.232278

146.9560Schwarz criterion

5.431424

-48.32278Hannan-Quinn criter.

5.271153

8.634036Durbin-Watson stat

2.609219

Common-Constant method selected when there are differences between the data-dimensional matrix in cross section. This model means that estimates the value of the constant $\alpha$ for all the dimensions of the cross section. Based on the results of the regression using methods common-Constant in Table 4.6 it can be concluded that the ROE, DER results are not significant with the acquisition probability> 0:05 $\alpha$. while PBV yield significant results with the acquisition probability $<\alpha$ 0:05. for results $R$-square $(\mathrm{R} 2)$ of the method of 0.618158 , explain the strong relationship between the independent variable and dependent variable.

Table 4. Results of Panel Data Regression Analysis with Random Effect Model

Dependent Variable: Y

Method: Panel EGLS (Cross-section random effects)

Date: 11/19/19 Time: 11:00

Sample: 20142018

Periods included: 5

Cross-sections included: 4

Total panel (balanced) observations: 20

Swamy and Arora estimator of component variances

\begin{tabular}{crrrr}
\hline \hline variable & coefficient & Std. Error & t-Statistic & Prob. \\
\hline \hline C & -1.461331 & 1.068302 & -1.367901 & 0.1902 \\
X1 & 5.823832 & 3.343299 & 1.741942 & 0.1007 \\
X2 & 0.044281 & 0.061081 & 0.724967 & 0.4789 \\
X3 & 3.332911 & 0.764073 & 4.362033 & 0.0005 \\
\hline \hline
\end{tabular}

Effects Specification

\begin{tabular}{lrr} 
& SD & Rho \\
\hline \hline Cross-section random & 0.000000 & 0.0000 \\
idiosyncratic random & 2.991963 & 1.0000 \\
\hline \hline
\end{tabular}

weighted Statistics

R-squared

Adjusted R-squared

$\mathrm{SE}$ of regression

F-statistic

Prob (F-statistic)
0.618158Mean dependent var

$0.546562 \mathrm{SD}$ dependent var

3.030635Sum squared resid

8.634036Durbin-Watson stat

0.001226
1.008440

4.500645

146.9560

2.609219

unweighted Statistics 
R-squared

0.618158 Mean dependent var

1.008440

Sum squared resid

146.9560Durbin-Watson stat

2.609219

Based on the results of the regression using Random Effect method can be concluded that all ROE and DER results were not significant with the acquisition probability $>\alpha$ 0:05 whereas PBV variable yielded significant results with the acquisition probability $<\alpha 0: 05$, For the results of the R-square $(\mathrm{R} 2)$ of this method gives a value of 0.618158 that explain the strong relationship between the independent variable and dependent variable.

Table 5. Chow Test

\author{
Redundant Fixed Effects Tests \\ Equation: Untitled \\ Test cross-section fixed effects
}

\begin{tabular}{lrrr}
\hline \hline Effects Test & statistics & df & Prob. \\
\hline \hline & & & \\
Cross-section F & 1.138761 & $(3.13)$ & 0.3699 \\
Cross-section Chi-square & 4.666486 & 3 & 0.1979 \\
\hline \hline
\end{tabular}

Results redundant fixed effect or likelihood ratio for this model has a greater probability value of Alpha (0.05), so that H0 rejected H1 accepted, the appropriate model from these results that the Common Effect Model (Because the probability value of 0.3699>0.05).

After doing the selection equation model with Chow Test the results obtained equation model is most appropriate for this research is a common effect equation model. Linear regression equation model panel data in this study were obtained equation as follows:

$$
Y=0.489972-6.668490 X 1-0.513448 X 2+0.170031 X 3
$$

Table 6. F Test

\begin{tabular}{cc}
\hline F-Statistic & 8634036 \\
Prob $($ F-Statistics $)$ & 0.001226 \\
\hline
\end{tabular}

Based on Table 6 it can be seen that the F-Stastistic $=8634036<3: 10$ (Ftabel) and has a probability value of F-Statistic $0.001226<0: 05$. So that the models used are not eligible to explain the influence of the independent variable on the dependent variable.

Table 7. The coefficient of determination (R2)

\begin{tabular}{ll}
\hline$R$-Squared & 0.618158 \\
Adjusted R-Squared & 0.546562 \\
\hline
\end{tabular}

Based on the results of such calculations in Table 7 above it can be seen that the influence of the independent variable on the dependent variable stock price visible Telecommunication subsector of Adjusted R-Squared value that is equal to 0.546562 or $54.6562 \%$. it indicates $54.6562 \%$ Of shares Return which may be explained by the variation of all independent variables of ROE, DER and PBV. While the rest of $100 \%-54.6562 \%=45.3438 \%$ explained by other independent variables were not examined. 
Table 8. $t$ Test

\begin{tabular}{lllll}
\hline \hline variable & coefficient & Std. Error & t-Statistic & Prob. \\
\hline \hline C & $-1,461,331$ & 1.08211 million & $-1,350,446$ & 0.1957 \\
ROE & 5823832 & 3386512 & 1719714 & 0.1048 \\
DER & 0.044281 & 0.061870 & 0.715716 & 0.4845 \\
PBV & 3332911 & 0.773949 & 4306372 & 0.0005 \\
\hline \hline
\end{tabular}

From the results of the model estimation, hypothesis testing is done in accordance with the purpose of the study was conducted. The t-test was conducted to determine the effect of ROE, DER, PBV andterhadap Stock returns The Company's Telecommunications Sector Sub partially (their own). The $t$-test is done by comparing the value of $t$ arithmetic with $t$ table. If $t>t$ table, then it is said to be a significant influence, and if $\mathrm{t}<\mathrm{t}$ table, then say the effect is not significant. Results of testing the hypothesis outlined below:

\section{Hypothesis 1 \\ Ho : ROE no positive effect on Stock Return \\ Ha : ROE positive influence on Stock Return}

Based on t test at $\alpha=5 \%$ in table 8 , the probability values ROE amounted 0.1048 or greater than 0.05 , it can be concluded ROE no significant effect on Stock Return. When viewed from t table at alpha of 0.05 (one tail) $\mathrm{df}=\mathrm{n}-1=20-1=19$ was 1.7291 , while the value of $\mathrm{t}$ count equal to $1,719,714$ (positive), Means $\mathrm{t}<\mathrm{t}$ table, then $\mathrm{HO}$ is rejected and $\mathrm{Ha}$ accepted. Thus, it can be concluded ROE no significant effect on Return Stocks in the Telecommunications Sector Sub Listed on the Stock Exchange in 20142018.

\section{Hypothesis 2 \\ Ho : DER no positive effect on Stock Return, Ha : DER positive influence on Stock Return,}

Based on t test at $\alpha=5 \%$ in table 8 , DER variable probability value of 0.4845 or greater than 0.05 , it can be concluded DER no significant effect on Stock Return. When viewed from $t$ table at alpha of 0.05 (one tail) $\mathrm{df}=\mathrm{n}-1=20-1=19$ was 1.7291 , while the value of $\mathrm{t}$ count equal to 0.715716 . Means $\mathrm{t}$ $<\mathrm{t}$ table, then Ho is rejected and Ha accepted. Thus, it can be concluded DER no significant effect on Return Stocks in the Telecommunications Sector Sub Listed on the Stock Exchange in 2014-2018.

\section{Hypothesis 3}

Ho : PBV not negatively affect the Stock Return.
Ha : PBV negatively affect the Stock Return.

Based on t test at $\alpha=5 \%$ at $4: 11$ table, a variable probability value PBV of 0.0005 or less than 0.05 , it can be concluded PBV significant effect on Stock Return. When viewed from t table at alpha of 0.05 (one tail) $\mathrm{df}=\mathrm{n}-1=20-1=19$ is 1.7291 , While the value of $\mathrm{t}$ count equal to 4,306 (positive), Means $\mathrm{t}>$ $\mathrm{t}$ table, then Ha Ho accepted and rejected. Thus, we can concludePBV positive and significant impact on Return Shares in the Sub-Sector Telecommunications Listed on the Stock Exchange in 2014-2018.

\section{CONCLUSION AND SUGGESTION}

The test result data by using E-views 9 obtained Effect Model Common models. Based on the analysis and discussion, it can be concluded as follows: 
Variable Return On Equity (ROE) had no significant effect on Return on Equity Sub-Sector Telecommunications Listed on the Stock Exchange from 2014 until 2018. This can be interpreted Investors assess the ROE as information instead responded in the negative to the stock return this can be seen from the sub-sector of Telecommunications require funds for expansion and going concern funding requirements can be obtained through retained earnings and Improvement of State Capital actually impact rebounding stock price drop ,

Variable Debt to Equity Ratio (DER) did not significantly influence stock return Sub-Sector Telecommunications Listed on the Stock Exchange from 2014 until 2018, These results indicate that the greater the value of DER signaling that venture capital structure more use of debt relative to equity causing investors' assessment of the company is getting worse, as a result investors tend to avoid stocks that have a high value in the Sub DER Telecommunications Sector Listed on the Stock Exchange from 2014 until 2018.

Variable Price to Book Value Ratio (PBV) positive and significant impact on Return Shares in the Sub-Sector Telecommunications Listed on the Stock Exchange from 2014 until 2018. PBV positive on stock returns means PVB has a high value it showed the higher the investors' assessment of the company concerned, this condition results in increasing a company's stock price, thus also expected to increase the level of return (return) of the company concerned.

\section{REFERENCE}

Abdullah, Mohammad Nayeem, Karuddin Parvez, Tarana Karim, and Rahat Bari Tooheen 2015. The Impact of Financial Leverage and Market Size on Stock Returns on the Dhaka Stock Exchange: Evidence from Selected Stocks in the Manufacturing Sector, International Journal of Economics, Finance, and Management Sciences, Vol. 3, No. 1, pp.10-15

Bodie, Z., Kane, A., \& Marcus, AJ (2008). Investments (7th Edition ed.). New York: McGrawHill.

Dita, Amalia Husna and Isrochmani Murtaqi. 2014. The Effect of net profit margin, price-tobook value and debt-to-equity ratio on Stock Return in the Indonesian consumer goods industry. Journal of Business and Management. Vol. 3, No. 3. pp. 305-315.

Gharaibeh, Adnan. 2014. Capital Structure, Liquidity, And Stock Returns. (European Scientific Journal, Vol. 10, No. 25, September 2014).

Ghi, Nha Tran. 2015. The Impact of Capital Structure and the Financial Performance on Stock Return of The Firm in Hose.International Journal of Information Research and Review. Vol.2, No. 6, pp.734-737.

Hasbi, Hariandy and Sarjito Surya. 2015. The Effect Of Capital Structure And Market Profitability Ratios On Stock Price In The Property Sector. Journal International. h 62736277. ISSN 1013-6277

Mahdaleta et al, 2016. Effects of capital structure and profitability on the corporate value with company size as the moderating variable of manufacturing companies listed on Indonesia Stock Exchange.

Martini, Ni Nyoman G Putu, Moeljadi and Djumahir et al. Factors effecting 2014. Value of Indonesia Public Firms Manufacturing Firm. International Journal of Business and Management Invention ISSN. 3 (2): 35-44 
Nuryaman.2015. The Influence Of Intellectual Capital On The Firm's Value With The Financial Performance As Intervening Variable. -Social Procedia And Behavioral Sciences, 2nd Global Conference On Business And Social Sciences (Gcbss-2015) On Multidisciplinary Perspectives On Management And Society, September 17 to 18, 2015, Bali, Indonesia, 211: 292-98. Doi: 10.1016 / J.Sbspro.2015.11.037

Rashid, Abdul. 2015. Effects of Ownership Structure, Capital Structure, Profitability and Company's Growth TowardsFirm Value. International Journal of Business and Management Invention, Vol. 4, pp. 25-31,

Ross. 1976.Journal of Economic Theory, Volume 13, Issue 3, December 1976, Pages 341360

Ross 1977. The Determination of Financial Structure: The Incentive-Signaling. Approach Author (s): Stephen A. Ross Source: The Bell Journal of Economics, Vol. 8, No. 1 (Spring, 1977), pp. $23-40$

Senyigit, Yigit Bora And Joseph Ag. 2014. Explaining the cross section of stock returns; A comparative study of the United States and Turkey. 2ndWorld Conference on Business, Economics and Management, Procedia-Social and Behavioral Sciences 109 (2014) 327 332. Zirve University: Turkey

Know, GP, and Susilo, DD (2017). Effect of Liquidity, Leverage and profitability to Firm Value (Dividend Policy as Moderating Variable) in Manufacturing Company of Indonesia Stock Exchange. Research Journal of Finance and Accounting, Vol.8, No.18

Tamuunu, Sonnia Cindy., \& FarlaneRumokoy. 2015. The Influence of Fundamental Factors On Stock Return. EMBA Journal Vol. 3 No. December 4th, 2015, p. 628-636. 